\title{
Study on Efficiency of Remediation of Seepage Containing Uranium with Phosphate as PRB Material
}

\author{
Jian Shen \\ School of Nuclear Resources Engineering \\ University of South China \\ Hengyang 421001, China \\ Zhenping Tang \\ School of Nuclear Resources Engineering \\ University of South China \\ Hengyang 421001, China
}

\author{
Junwen Lv \\ School of Environment Protection and Safety Engineering \\ University of South China \\ Hengyang 421001, China \\ *Corresponding author
}

Yang Lv

School of Nuclear Science and Technology

University of South China

Hengyang 421001, China

\begin{abstract}
The efficiency of remediation of seepage containing uranium using phosphate as PRB material was investigated by batch experiment and column experiment. The batch experiment showed the uranium concentration in leachate was gradually decreased with the increase of $\mathrm{Ca}_{3}\left(\mathrm{PO}_{4}\right)_{2}$ dosage and contact temperature, the optimum dosing amount of $\mathrm{Ca}_{3}\left(\mathrm{PO}_{4}\right)_{2}$ is $0.13 \mathrm{mg}$ at $25^{\circ} \mathrm{C}$ and $30^{\circ} \mathrm{C}, 35^{\circ} \mathrm{C}$, however ,is $0.11 \mathrm{mg}$ at $40^{\circ} \mathrm{C}$. The column experiment showed calcium phosphate could reduce slightly concentration of uranium in leachate, removal rate of uranium was not high ,the range of removal rate was from $34.2 \% \sim 73.5 \%$ in the early stage of experiment , and was from $12.4 \% \sim 23.0 \%$ in middle and later stage of experiment. Thus, using $\mathrm{Ca}_{3}\left(\mathrm{PO}_{4}\right)_{2}$ as PRB material to remedy acidi seepage containing uranium from tailings is not feasible.
\end{abstract}

\section{Keywords-seepage; remediation; phosphate; PRB}

\section{INTRODUCTION}

Uranium is not only the most basic raw materials in nuclear industry, but also important strategic materials. As countries develop nuclear power, Uranium resources demand is more and more big. According to statistics, in recent years, the global natural uranium production has 58394t, including about $1500 \mathrm{t}$ in China [1]. With the increase of the demand of uranium, a lot of uranium ore is mined to cause serious environmental contamination around uranium mining area. Especially, a lot of uranium waste rock, and uranium tailings piled up in the environment, interacted with the water, such as surface water and groundwater flows through them, generating plenty of seepage containing uranium and other metals and nonmetal ions in the waste rock and tailings by leaching out. Due to the characteristics of concealment and discontinuity, the seepage was difficult in control, which is easy to cause soil and groundwater contamination. Thus the effective treatment of seepage containing uranium has become a hotspot at home and abroad. In order to treat seepage from uranium waste rock and mill tailings, the U.S. Environmental Protection Agency proposed the Permeable Reactive Barrier (PRB), an innovative technology for remediation of contaminated groundwater in 1982. The PRB was installed at the location where flows polluted through; the PRB could remove pollutants in flows through adsorption, precipitate, biological degradation, and so on. PRB technology was researched in the early $1990 \mathrm{~s}[2,3]$. In China, the technology and material were constantly researched[4,5], and were used in engineering practice, for example, Jun-wen Lv studied the feasibility of treating acidic seepage from mill tailings with $\mathrm{CaO}$ as PRB material, and constructed the PRB at a uranium mine in Southwest[6,7]. However PRB technology will exist some problems in the practical application, such as, due to precipitation reaction, the PRB permeability and the activity of reaction materials decrease, and especial PRB material causes secondary pollution, for example $\mathrm{CaO}$ as $\mathrm{PRB}$ material leads to alkali pollution. Previous research found phosphate could remove uranium in solution[8-10].In this experiment, the phosphate as PRB material, to avoid secondary pollution under the condition of the $\mathrm{pH}$ more than 4.5, This research on the influence of phosphate on the precipitation of uranium in wastewater and on the leaching of uranium from waste rock or mill tailings was carried out through batch experiment, and removal of the uranium in seepage with PRB was simulated through the column experiment to investigate the efficiency and feasibility.

\section{MATERIALS AND METHODS}

\section{A. Mill Tailings Sample}

The mill tailings sample was collected from South of China, the samples were crushed with ball through 100 mesh sieve, and was dried at $104^{\circ} \mathrm{C}$. The uranium content in the sample is about $0.0788 \%$. The main composition of sample were analyzed with XRF, the result was shown in the Table 1.

TABLE 1. THE XRF ANALYSIS OF THE SAMPLE

\begin{tabular}{|l|l|l|l|l|l|l|l|}
\hline $\begin{array}{l}\text { Mineral } \\
\text { composition }\end{array}$ & $\mathrm{Na}_{2} \mathrm{O}$ & $\mathrm{MgO}$ & $\mathrm{Al}_{2} \mathrm{O}_{3}$ & $\mathrm{SiO}_{2}$ & $\mathrm{~K}_{2} \mathrm{O}$ & $\mathrm{CaO}$ & $\mathrm{Fe}_{2} \mathrm{O}_{3}$ \\
\hline Content $/ \%$ & 0.37 & 2.01 & 15.86 & 60.08 & 3.42 & 3.17 & 7.77 \\
\hline
\end{tabular}

\section{B. Bath Experiments}

By bath experiments, the research objective is influence of phosphate on the leaching of uranium under temperature and 
amount. Per $10.00 \mathrm{~g}$ tailings samples was put into a series of $250 \mathrm{ml}$ conical flask respectively, and the calcium phosphate (dosage, see table 2) was added to them in turn, finally, $100 \mathrm{ml}$ of sulphuric acid solution with $\mathrm{pH} 2.0$ was joined in. The configured mixture has been shocked with velocity of $150 \mathrm{r} / \mathrm{min}$ for $3 \mathrm{~h}$ in the water bath temperature oscillator at $25{ }^{\circ} \mathrm{C}$ and $30{ }^{\circ} \mathrm{C}, 35{ }^{\circ} \mathrm{C}$ and $40{ }^{\circ} \mathrm{C}$, respectively. The mixture was filtered, and the uranium concentration in filter was analyzed.

TABLE 2. THE AMOUNT OF ADDING CALCIUM PHOSPHATE

\begin{tabular}{|l|l|l|l|l|l|l|c|}
\hline & 1 & 2 & 3 & 4 & 5 & 6 & 7 \\
\hline $\mathrm{Ca}_{3}\left(\mathrm{PO}_{4}\right)_{2} / \mathrm{mg}$ & 0.00 & 0.05 & 0.07 & 0.09 & 0.11 & 0.13 & 0.15 \\
\hline
\end{tabular}

\section{Column Experiments}

The setup of the column experiment is shown in Fig. 1, containing two columns one was filled with calcium phosphate (No.1), another was without (No.2),compared their influence on leaching of uranium from tailings. Column experiments were conducted using Perspex columns with an inner diameter of $4.85 \mathrm{~cm}$ and a height of $50 \mathrm{~cm}$. Height of 5 $\mathrm{cm}$ quartz sands were put in the top and bottom of the column as back flushing and counter pressure layer to eliminate the effect of fluid on the tailings sample in the column and nylon gauze was placed between tailings, calcium phosphate and quartz sands to keep the particle from flowing with lea chant. The packing conditions of uranium tailings in two columns (sample amount, height of bed length) are almost same (see Table3).

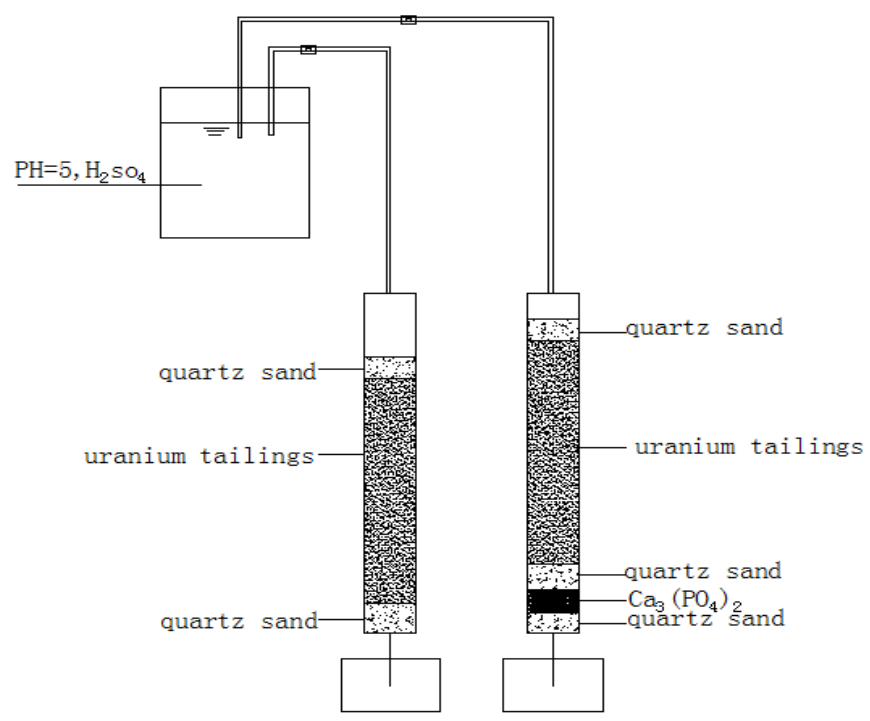

FIGURE 1. SETUP OF THE COLUMN EXPERIMENT

TABLE 3. CHARACTERISTICS OF THE TWO COLUMN EXPERIMENTS

\begin{tabular}{cccl}
\hline Column & Uranium tailing amount $/ \mathrm{g}$ & calcium phosphate $/ \mathrm{g}$ & Bed length $/ \mathrm{cm}$ \\
\hline No.1 & 653.0 & 0 & 36 \\
No.2 & 653.0 & 20 & 38 \\
\hline
\end{tabular}

D. Analysis Method

Metal uranium (VI) in solution was analyzed by Laser
Uranium Analyzer. The $\mathrm{pH}$ value of leach ate was analyzed by $\mathrm{pH}$ meter.

\section{RESULTS AND DISCUSSION}

\section{A. Batch Experiment Results}

The influence of $\mathrm{Ca}_{3}\left(\mathrm{PO}_{4}\right)_{2}$ on leaching uranium by $\mathrm{H}_{2} \mathrm{SO}_{4}$ solution with $\mathrm{pH} 2.0$ was investigated by batch experiments under different conditions in terms of $\mathrm{Ca}_{3}\left(\mathrm{PO}_{4}\right)_{2}$ dosage, and contact temperature. The result of investigation see Fig.2,and showed that amount of uranium leaching was gradually decreased with the increase of $\mathrm{Ca}_{3}\left(\mathrm{PO}_{4}\right)_{2}$ dosage and contact temperature, indicating Phosphate can inhibit the leaching of uranium from tailings, which $\mathrm{PO}_{4}{ }^{3-}$ from $\mathrm{Ca}_{3}\left(\mathrm{PO}_{4}\right)_{2}$ ionization and $\mathrm{U}^{6+}$ formed urinal ion, the higher the temperature ,the more $\mathrm{Ca}_{3}\left(\mathrm{PO}_{4}\right)_{2}$, the greater the ability of ionization, the more formation of $\mathrm{PO}_{4}{ }^{3-}$, the optimum dosing amount of $\mathrm{Ca}_{3}\left(\mathrm{PO}_{4}\right)_{2}$ is $0.13 \mathrm{mg}$ at $25^{\circ} \mathrm{C}$ and $30^{\circ} \mathrm{C}, 35^{\circ} \mathrm{C}$, however, is $0.11 \mathrm{mg}$ at $40^{\circ} \mathrm{C}$.

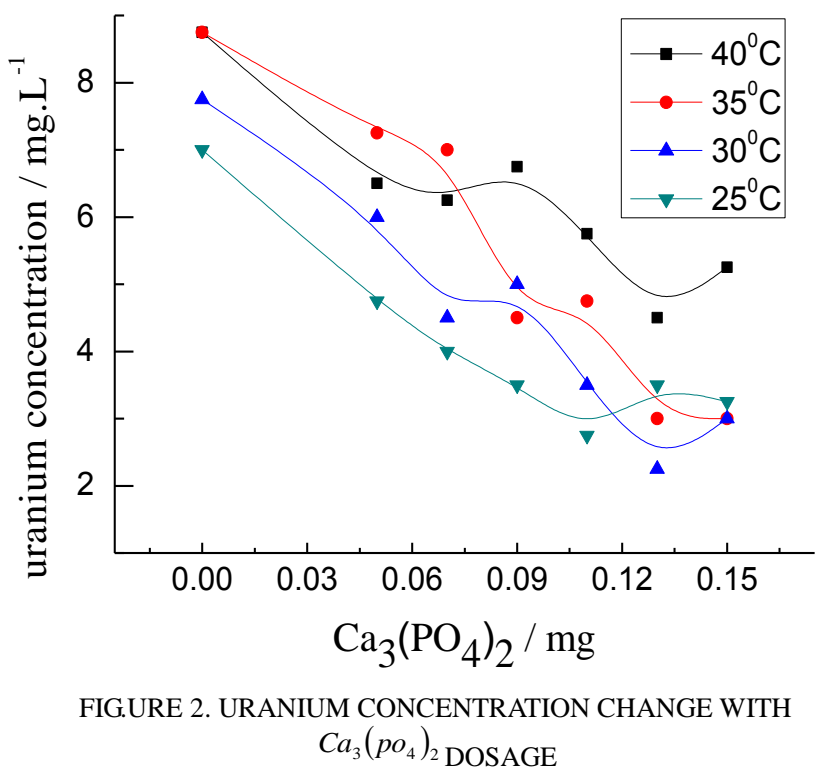

\section{B. Column Experiment Results}

The value of $\mathrm{pH}$ in the leachant was set to about 5 with sulfuric acid in order to simulate acidic rain leaching tailing during the column experiment. The uranium concentration and the volume of leachate have been determinated once every 7 hours until the uranium concentration of the leachate hardly change. This experiment lasted about 30 days.

The time variation of uranium concentration in leachate was shown in the fig. 3 . The result of the two columns showed the concentration of uranium in leachate dramatically reduce in the first five days of experiment, then slowly decreased from 6th day to 8th day, at last, keep hardly same until the end of experiment. However there was difference between No.1 and No.2, the concentration of uranium from No.2 was lower than from No.1, which indicating calcium phosphate can remove uranium from leachate, the range of removal rate of uranium was from $34.2 \% \sim 73.5 \%$ in the first five days of experiment, was from $12.4 \% \sim 23.0 \%$ after six days, until the 
end of the experiment.

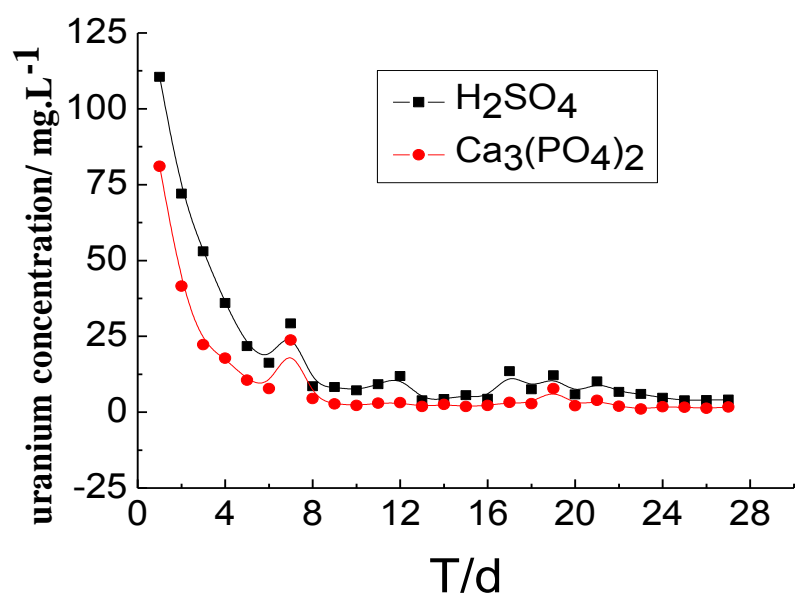

FIGURE 3. URANIUM CONCENTRATION CHANGE WITH TIME

Due to the strong complication between phosphorus and uranium, the phosphate added affects on the adsorption of uranium in water. In general. under the condition of acid, increasing phosphate concentration can improve the adsorption of uranium by some mineral, such as goethite, $\mathrm{UO}_{2} \mathrm{HPO}_{4} \cdot 4 \mathrm{H}_{2} \mathrm{O}$ crystal is formed when concentrations of uranium and phosphate in solution are very high, under the condition of phosphate type uranyl complex supersaturated, new surface complex formed by certain minerals promotes the precipitation of uranyl phosphate, resulting in reducing the concentration of uranium in water [11].

In the column experiment, due to high $\mathrm{pH}$ value in leachant and low uranium content in mill tailings, uranium concentration in leachate was low, meanwhile, during leaching uranium, due to $\mathrm{Ca}_{3}\left(\mathrm{PO}_{4}\right)_{2}$ ionization difficult in liqueous, $\mathrm{PO}_{4}{ }^{3-}$ concentration was low, too, not enough to generate a large number of precipitation of phosphate uranyl, resulting in low removal rate of uranium. However, the uranium concentration in the leachate during the initial experiment was higher than during the mid-late experiment, making the removal rate of uranium during the initial was bigger than during the mid-late, because the bigger the concentration of uranium, the greater precipitate of phosphate uranyl was formed.

\section{CONCLUSIONS}

This study clearly showed phosphate can reduce the uranium concentration in the leachate. Batch experiments showed uranium concentration in leachate was reduce with increasing phosphate and the contact temperature, the optimum dosing amount of $\mathrm{Ca}_{3}\left(\mathrm{PO}_{4}\right)_{2}$ is $0.13 \mathrm{mg}$ at $25^{\circ} \mathrm{C}$ and $30^{\circ} \mathrm{C}, 35^{\circ} \mathrm{C}$, however ,is $0.11 \mathrm{mg}$ at $40^{\circ} \mathrm{C}$. Moreover, column experiments showed calcium phosphate can reduce slightly concentration of uranium in leachate, removal rate of uranium is not high, the range of removal rate was from $34.2 \%$ 73.5\% in the early stage of experiment, and was from $12.4 \%$ 23.0\% in middle and later stage of experiment, Thus it is not feasible with $\mathrm{Ca}_{3}\left(\mathrm{PO}_{4}\right)_{2}$ as PRB material to remedy acidi seepage containing uranium from tailings.

\section{ACKNOWLEDGEMENT}

The project was funded by the National Natural Science Foundation of China (grant No.11275092).

\section{REFERENCE}

[1] Guo Z F, Wang Z. The production of global natural uranium in 2012[J]. Global Nuclear News, 2013, (07):22-25.

[2] Du L Z, Zhang L Y, Wang L D.PRB technology of heavy metal ions in groundwater treatment research $[\mathrm{J}]$. The environmental pollution and the prevention and control, 2007, 29(8).

[3] Gillham R W, OHeannesin S F .Enhanced degradation of halogenated aliphatics by zero-valant iron[J].GroundWater32(6):958 967.

[4] Gao F, Pan Z P. PRB technical treatment of heavy metal pollution of groundwater research review $[\mathrm{J}]$. Journal of chemical industry of guangdong province, 2014, (17): 80-81.

[5] Liu L, Xu W B, Gan S F. PRB technology in the research development of groundwater pollution repair [J]. Water resources protection, 2006.11, 76-80.

[6] LV Junwen, Xiong Zhenwei, Yang Yong. The Feasibility Study of Using PRB Technology to Remedy Acid Seepage Water from Uranium mill-tailings [J]. Journal of HuaiHua University 2007.02, 65-66.

[7] LV Junwen, YangYong,Xu Lechang. Remediation of Out-of-Service Tailing Reservoir of A Uranium M ill in Southwest China, Metal Mine. 2007, 373(7): 83-86.

[8] Dai W Z. Phosphate method and treatment of wastewater containing uranium [J]. Journal of uranium mining and metallurgy, 1991.08, and 48-52.

[9] Berto S, Crea F,Daniele P G, et al. Advances in the investigation of dioxouranium(VI) complexes of interest for natural fluids[J]. Coordination Chemistry Reviews, 2012, 256(1-2):63-81.

[10] Kirishima A, Kimura T, Tochiyama O, et al. Speciation study on complex formation of uranium(VI) with phosphate and fluoride at high temperatures and pressures by time-resolved laser-induced fluorescence spectroscopy[J]. Radiochimica Acta, 2004, 92(12):889-896.

[11] Abhas Singh, Kai-Uwe Ulrich, Daniel E. Giammar. Impact of phosphate on $\mathrm{U}(\mathrm{VI})$ immobilization in the presence of goethite[J]. Geochimica et Cosmochimica Acta. 2010 (74):6324-6343. 